\title{
Elderly Asian Patients Have Lower Revascularisation Rates and Poorer Outcomes for ST-Elevation Myocardial Infarction Compared to Younger Patients
}

James X $\underline{\text { Cai }},{ }^{1} M B B S, M R C P(U K)$, Jonathan $\underline{\text { Yap }},{ }^{1}$ MBBS, MRCP (UK), MPH, Fei Gao, ${ }^{2}$ PhD, CStat, Tian Hai Koh, ${ }^{1}{ }_{M B B S,}$ MMed (Int), Khim Leng Tong, ${ }^{3} M B B S, M R C P(U K), F R C P\left(\right.$ Glasgow), Hean Yee Ong, ${ }^{4}$ MBBS, FRCP (Edin), FAMS (Cardiology), Pipin Kojodjojo, ${ }^{5}$ MBBS (UK), MRCP (UK), PhD (UK), Huay Cheem Tan, ${ }^{6}$ MBBS, MMed (Int Med), FRCP (UK), Marcus EH Ong, ${ }^{7}$ MBBS, FRCSEd (A\&E), MPH, David $\underline{\text { Foo }},{ }^{8}$ MBBS, MRCP (UK), FAMS (Cardiology), Bernard Ee, ${ }^{9}{ }_{M B B S,}$ MRCP (UK), FRCP, Lip Ping Low, ${ }^{10}$ MBBS, FRACP (Aus), FAMS, Paul Chui,${ }^{11}{ }_{M B B S,}$ DMJ, MRCPath,

Khung Keong Yeo, ${ }^{1}$ MBBS, ABIM (Int Med, US), ABIM (Cardiology, US)

\begin{abstract}
Introduction: There is limited information on elderly patients presenting with STelevation myocardial infarction (STEMI). This study aimed to study the outcomes of elderly Asian patients with STEMI compared to younger patients. Materials and Methods: The study utilised data from 2007 to 2012 from the Singapore Myocardial Infarction Registry, a mandatory national population-based registry. Elderly patients were defined as $\geq 80$ years of age, middle-aged to old (MAO) patients were defined as $45-80$ years of age and young patients were defined as $\leq \mathbf{4 5}$ years of age. The primary outcome of the study was 1-year mortality and secondary outcomes included in-hospital complications and mortality. Results: There were 12,409 STEMI patients with $1207(9.7 \%)$ elderly patients, $10,093(81.3 \%)$ MAO patients and $1109(8.9 \%)$ young patients. Elderly patients had more cardiovascular risk factors and lower rates of total percutaneous coronary intervention $(26.0 \%$ vs $72.4 \%$ vs $85.5 \%$, respectively; $P<0.0001)$ compared to $\mathrm{MAO}$ and young patients. They had higher 1 -year mortality $(60.6 \%$ vs $18.3 \%$ vs $4.1 \%$, respectively; $P<0.0001)$ when compared to MAO and young patients. Conclusion: Elderly patients with STEMI have poorer outcomes than MAO and young patients. This is potentially attributable to a myriad of factors including age, higher burden of comorbidities and a lesser likelihood of receiving revascularisation and guideline-recommended medical therapy.
\end{abstract}

Ann Acad Med Singapore 2020;49:3-14

Key words: Coronary artery bypass graft, Percutaneous coronary intervention

\section{Introduction}

ST-elevation myocardial infarction (STEMI) has been well studied in many real-world populations but there are limited data on patients at the extremes of ages. ${ }^{1,2}$ Age is a major risk factor of ischaemic heart disease. ${ }^{3}$ In developed countries with an ageing population, the prevalence of the elderly presenting with STEMI is increasing. ${ }^{4-6}$ Elderly patients have more comorbidities and primary percutaneous coronary intervention (PCI) in the elderly has also been associated with increased morbidity and mortality. ${ }^{6-9}$ Regardless, elderly patients still benefit from revascularisation when indicated. ${ }^{10-13}$ On the other hand, patients aged $\leq 45$ years old - while uncommon-represent a significant minority of patients with STEMI, with an incidence ranging from $2-10 \% .{ }^{14-16}$ Young patients have been described to have a different risk profile from the normal population - with obesity and smoking being more prevalent $^{15-18}$ and ethnic differences previously described in Asian populations. ${ }^{19,20}$ Young patients have also been described to have better in-hospital and long-term outcomes

\footnotetext{
${ }^{1}$ Department of Cardiology, National Heart Centre Singapore, Singapore

${ }^{2}$ National Heart Research Institute Singapore, National Heart Centre Singapore, Singapore

${ }^{3}$ Department of Cardiology, Changi General Hospital, Singapore

${ }^{4}$ Department of Cardiology, Khoo Teck Puat Hospital, Singapore

${ }^{5}$ Department of Cardiology, Ng Teng Fong General Hospital, Singapore

${ }^{6}$ National University Heart Centre Singapore, Singapore

${ }^{7}$ Department of Emergency Medicine, Singapore General Hospital, Singapore

${ }^{8}$ Department of Cardiology, Tan Tock Seng Hospital, Singapore

${ }^{9}$ Bernard Ee Cardiac Clinic, Gleneagles Medical Centre, Singapore

${ }^{10}$ Low Cardiology Clinic, Mount Elizabeth Medical Centre, Singapore

${ }^{11}$ Forensic Medicine Division, Health Sciences Authority, Singapore

Address for Correspondence: Adj A/Prof Yeo Khung Keong, Department of Cardiology, National Heart Centre Singapore, 5 Hospital Drive, Singapore 169609.

Email: yeo.khung.keong@singhealth.com.sg
} 
with lower mortality and morbidity rates. ${ }^{14-17}$ This study aimed to describe the clinical characteristics, in-hospital and long-term outcomes of elderly patients aged $\geq 80$ years old with STEMI and young patients aged $\leq 45$ years old when compared to middle-aged to old (MAO) patients aged $45-80$ years old. We hypothesised that elderly patients with STEMI will have lower rates of revascularisation and poorer outcomes as compared to MAO and young patients.

\section{Materials and Methods}

\section{Data Sources}

The study utilised data from 2007 to 2012 from the Singapore Myocardial Infarction Registry (SMIR), a national population-based registry coordinated by the National Registry of Diseases Office (NRDO). Singapore's NRDO was established in 2001. It is a state-mandated reporting programme that collects data on key non-communicable diseases such as acute myocardial infarction (AMI), stroke, end-stage renal failure and cancer. All Singapore residents have a unique National Registration Identity Card (NRIC) number, which allows tracking of mortality and hospital admissions. The study utilised AMI, stroke and death data from the NRDO from 2007 to 2012. Data on clinical outcomes were collected until 2014. Index events of AMI were identified and the data collected is described below. The study was confined to Singapore residents (citizens and permanent residents).

The SMIR ${ }^{21}$ is a part of the NRDO that collects data on all AMI in Singapore. All hospitals are legally required to reportAMI cases to this registry. In summary, demographics, clinical characteristics and outcomes (death, AMI and strokes) for index patients in the registry are obtained from various sources, which include MediClaim listings from the Ministry of Health, Hospital In-patient Discharge Summary (HIDS), cardiac biomarkers from laboratories and death data from the Registry of Births and Deaths of the Ministry of Home Affairs. These different sources of data provide near $100 \%$ coverage of AMI notifications.

Name lists from MediClaims, HIDS and the Death Registry were merged using the patients' NRIC number to derive the master patient list, from which the patient list for each hospital was generated. Cases extracted from MediClaims, HIDS and the Death Registry were coded based on the International Classification of Diseases $9^{\text {th }}$ Revision (ICD-9 Clinical Modification). ${ }^{22}$ ICD-9 code 410 was used for STEMI cases diagnosed in 2007 to 2011 while ICD-10 codes I21 and 122 were used for STEMI cases diagnosed in 2012 to 2013. A team of registry coordinators, comprising trained nurses reviewed each case on-site at every hospital to ensure data accuracy. Once the cases were verified, data was captured from electronic medical records and case notes, and entered into the electronic registry forms. STEMI cases were identified through the same process. Recurrence of AMI after 28 days of a recorded AMI episode was counted as another episode. To ensure data accuracy of at least $95 \%$ and inter-rater reliability (Kappa coefficient) of $\geq 75 \%$, a separate team of qualified nurses was tasked to perform an annual audit of the data.

\section{Study Population}

The study utilised data from all STEMI patients in the SMIR from 2007 to 2012. The patients were arbitrarily divided into 3 different age groups. Young patients were defined as patients $\leq 45$ years of age, MAO patients were defined as $45-80$ years of age and elderly patients were defined as $\geq 80$ years of age (with the age of patients rounded down to the nearest whole number).

\section{Outcomes}

The primary outcome of the study was 1-year mortality. Secondary outcomes included 2-year mortality and inhospital complications such as heart failure, arrhythmia and stroke.

\section{Statistical Analysis}

Clinical characteristics were compared between the young, MAO and elderly patient groups using KruskalWallis equality-of-populations rank or chi-square test as appropriate. Survival time was measured from index hospital admission for STEMI to the date of all-cause death or date of censor (31 December 2014). Univariate Cox regression models were used to assess the significance of clinical predictors (demographics, risk factors and clinical presentation) for 1-year mortality. Adjusted Cox regression models were analysed with variables that have $P$ value $<0.05$ from univariate analysis. The hazard ratios for death and their corresponding 95\% confidence intervals were derived by Cox regression. This was done for all patients and separately for 3 age groups. Unadjusted Kaplan-Meier survival curve was plotted for 1-year mortality comparing the 3 age groups. Stata Version 13 software was used for the analysis.

The Institutional Review Board waived the requirement for ethics approval. The data utilised for this study was nonidentifiable as it was collected and integrated by NRDO.

\section{Results}

There were 12,409 STEMI patients recorded between 2007 and 2012. Of these, there were 1207 (9.7\%) elderly, 10,093 (81.3\%) MAO and 1109 (8.9\%) young patients. Table 1 shows the key demographic and clinical characteristics of the 3 groups. Compared to MAO and young patients, 
elderly patients had more cardiovascular risk factors such as hypertension, diabetes mellitus, having previous AMI or coronary artery bypass graft $(\mathrm{CABG})($ all: $P<0.0001)$. However, they had lower rates of smoking compared to MAO and young patients ( $26.4 \%$ vs $56.8 \%$ vs $75.2 \%$, respectively; $P<0.0001$ ), as well as lower median body mass index (BMI) (21.7 vs 24.5 vs 26.6 , respectively; $P=0.0001$ ).

Table 2 describes the treatment modalities in the 3 age groups, with fewer elderly patients undergoing revascularisation with $\mathrm{PCI}, \mathrm{CABG}$ or thrombolysis compared to MAO and young patients. Table 3 shows the rate of in-hospital outcomes. Elderly patients had higher rates of in-hospital complications such as heart failure, atrial fibrillation, acute renal failure and strokes compared to MAO and young patients (all: $P<0.0001$ ). They also had significantly higher in-hospital mortality ( $38.5 \%$ vs $11.2 \%$ vs $2.17 \%$, respectively; $P<0.0001$ ).

Multivariate independent predictors of 1-year mortality of young, MAO and elderly patients are listed in Table 4. The full details of the independent predictors of 1-year mortality are found in Supplementary Tables 1-4. Renal impairment was a significant independent predictor of 1 -year mortality in the elderly, MAO and young patients (hazard ratio [HR] 1.0017, 95\% confidence interval [CI] 1.0007-1.0028; HR 1.0006, 95\% CI 1.0001-1.0010; HR $1.01,95 \%$ CI 1.00-1.02; respectively). Statin usage was

Table 1. Characteristics of Study Population

\begin{tabular}{|c|c|c|c|c|c|}
\hline Variable & $\begin{array}{l}\text { Young Patients } \\
\quad(n=1109)\end{array}$ & $\begin{array}{l}\text { Middle-Aged to Old } \\
\text { Patients }(n=10,093)\end{array}$ & $\begin{array}{l}\text { Elderly Patients } \\
\qquad(\mathrm{n}=\mathbf{1 2 0 7})\end{array}$ & $\begin{array}{c}\text { Total } \\
(\mathrm{n}=12,409)\end{array}$ & $P$ Value \\
\hline \multicolumn{6}{|l|}{ Demographics } \\
\hline Male, n (\%) & $1035(93.3)$ & $8161(80.9)$ & $482(39.9)$ & $9678(78.0)$ & $<0.0001$ \\
\hline Age (years, mean $\pm \mathrm{SD}$ ) & $39.8 \pm 4.1$ & $60.7 \pm 9.6$ & $86.2 \pm 4.3$ & $61.3 \pm 13.4$ & $<0.0001$ \\
\hline Length of stay (days, mean \pm SD) & $4.7 \pm 9.5$ & $6.5 \pm 10.3$ & $9.4 \pm 13.2$ & $6.6 \pm 10.6$ & 0.0001 \\
\hline Ethnicity, n (\%) & & & & & $<0.0001$ \\
\hline Chinese & $584(52.7)$ & $6495(64.4)$ & $978(81.0)$ & 8057 (64.9) & \\
\hline Malay & $235(21.2)$ & $2041(20.2)$ & $124(10.3)$ & $2400(19.3)$ & \\
\hline Indian & $267(24.1)$ & $1406(13.9)$ & $87(7.2)$ & $1760(14.2)$ & \\
\hline Others & $23(2.1)$ & $151(1.5)$ & $18(1.5)$ & $192(1.6)$ & \\
\hline Median BMI $\left(\mathrm{kg} / \mathrm{m}^{2}\right)(\mathrm{IQR})$ & $26.2(23.9-29.2)$ & $24.2(22.0-26.7)$ & $21.3(18.7-24.3)$ & $24.2(21.8-26.8)$ & 0.0001 \\
\hline \multicolumn{6}{|l|}{ Risk factors, n (\%) } \\
\hline Hypertension & $404(36.4)$ & $5684(56.3)$ & $856(70.9)$ & $6944(56.0)$ & $<0.0001$ \\
\hline Diabetes mellitus & $197(17.8)$ & $3350(33.2)$ & $402(33.3)$ & 3949 (31.8) & $<0.0001$ \\
\hline Hyperlipidaemia & $333(30.0)$ & $4666(46.2)$ & $529(43.8)$ & $5528(44.6)$ & $<0.0001$ \\
\hline Previous AMI & $63(5.7)$ & $1102(10.9)$ & $196(16.2)$ & $1364(11.0)$ & $<0.0001$ \\
\hline Previous CABG & $1(0.1)$ & $172(1.7)$ & $27(2.2)$ & $200(1.6)$ & $<0.0001$ \\
\hline Previous PCI & $55(5.0)$ & $745(7.4)$ & $47(3.9)$ & $847(6.8)$ & $<0.0001$ \\
\hline Ever smoker & $834(75.2)$ & $5733(56.8)$ & $319(26.4)$ & $6886(55.5)$ & $<0.0001$ \\
\hline Killip class on admission, $\mathrm{n}(\%)$ & & & & & $<0.0001$ \\
\hline I & $1013(91.3)$ & $7938(78.7)$ & $799(66.2)$ & $9750(78.6)$ & \\
\hline II & $36(3.3)$ & $872(8.6)$ & $186(15.4)$ & $1094(8.8)$ & \\
\hline III & $17(1.5)$ & $515(5.1)$ & $107(8.9)$ & $639(5.2)$ & \\
\hline IV & $40(3.6)$ & $679(6.7)$ & $90(7.5)$ & $809(6.5)$ & \\
\hline Anterior & $573(51.7)$ & $5414(53.6)$ & $721(59.7)$ & $6708(54.1)$ & $<0.0001$ \\
\hline Inferior & $508(45.8)$ & $4389(43.5)$ & $415(34.4)$ & $5312(42.8)$ & $<0.0001$ \\
\hline Lateral & $132(11.9)$ & 1205 (11.9) & $149(12.3)$ & $1486(12.0)$ & 0.92 \\
\hline Right ventricular & $57(5.1)$ & $681(6.8)$ & $51(4.2)$ & $789(6.4)$ & 0.001 \\
\hline Posterior & $135(12.2)$ & $1402(13.9)$ & $136(11.3)$ & $1673(13.5)$ & 0.017 \\
\hline
\end{tabular}

ACE: Angiotension converting enzyme; AMI: Acute myocardial infarction; BMI: Body mass index; CABG: Coronary artery bypass graft; IQR: Interquartile range; PCI: Percutaneous coronary intervention; SD: Standard deviation 
Table 1. Characteristics of Study Population (Cont'd)

\begin{tabular}{|c|c|c|c|c|c|}
\hline Variable & $\begin{array}{l}\text { Young Patients } \\
\quad(n=1109)\end{array}$ & $\begin{array}{l}\text { Middle-Aged to Old } \\
\text { Patients }(n=10,093)\end{array}$ & $\begin{array}{l}\text { Elderly Patients } \\
\qquad(\mathrm{n}=\mathbf{1 2 0 7})\end{array}$ & $\begin{array}{c}\text { Total } \\
(\mathrm{n}=\mathbf{1 2 , 4 0 9 )}\end{array}$ & $P$ Value \\
\hline \multicolumn{6}{|l|}{ Median laboratory data (IQR) } \\
\hline Troponin I peak (ng/mL) & $54.2(18.3-80)$ & $49.8(11.8-80)$ & $36.1(4.7-80)$ & $46.2(11.0-80)$ & 0.0001 \\
\hline High-density lipoprotein (mmol/L) & $0.9(0.8-1.1)$ & $1.0(0.8-1.2)$ & $1.1(0.9-1.4)$ & $1.0(0.8-1.2)$ & 0.0001 \\
\hline Triglycerides (mmol/L) & $1.7(1.2-2.5)$ & $1.3(1.0-1.9)$ & $1.0(0.8-1.4)$ & $1.3(1.0-1.9)$ & 0.0001 \\
\hline Haemoglobin A1c (\%) & $6.3(5.6-9.1)$ & $6.4(5.8-8.2)$ & $6.2(5.6-6.9)$ & $6.4(5.7-8.2)$ & 0.0001 \\
\hline Haemoglobin (g/dL) & $15.4(14.4-16.3)$ & $14.3(13.0-15.4)$ & $11.9(10.4-13.3)$ & $14.3(12.8-15.4)$ & 0.0001 \\
\hline Creatinine $(\mu \mathrm{mol} / \mathrm{L})$ & $86(74-99)$ & $93(78-116)$ & $115(84-171)$ & $93.0(78-117)$ & 0.0001 \\
\hline \multicolumn{6}{|l|}{ Discharge medications, n (\%) } \\
\hline Beta-blocker & $963(90.0)$ & $7582(86.4)$ & $486(70.6)$ & $9031(85.7)$ & $<0.0001$ \\
\hline ACE inhibitor & $789(73.7)$ & $6548(74.6)$ & 407 (59.2) & $7744(73.5)$ & $<0.0001$ \\
\hline Statin & $1038(97.0)$ & $8355(95.2)$ & $592(86.1)$ & 9985 (94.8) & $<0.0001$ \\
\hline
\end{tabular}

ACE: Angiotension converting enzyme; AMI: Acute myocardial infarction; BMI: Body mass index; CABG: Coronary artery bypass graft; IQR: Interquartile range; PCI: Percutaneous coronary intervention; SD: Standard deviation

Table 2. Treatment Modalities

\begin{tabular}{|c|c|c|c|c|c|}
\hline Variable & $\begin{array}{l}\text { Young Patients } \\
\quad(n=1109)\end{array}$ & $\begin{array}{l}\text { Middle-Aged to Old } \\
\text { Patients }(n=10,093)\end{array}$ & $\begin{array}{l}\text { Elderly Patients } \\
\quad(n=1207)\end{array}$ & $\begin{array}{c}\text { Total } \\
(n=12,409)\end{array}$ & $P$ Value \\
\hline \multicolumn{6}{|c|}{ Percutaneous coronary intervention, n (\%) } \\
\hline Primary & $802(72.3)$ & $6254(62.0)$ & $279(23.1)$ & $7335(59.1)$ & $<0.0001$ \\
\hline Rescue/staged & $170(15.3)$ & $1236(12.3)$ & $41(3.4)$ & $1447(11.7)$ & $<0.0001$ \\
\hline \multicolumn{6}{|c|}{ Coronary artery bypass graft, n (\%) } \\
\hline Total & $15(1.4)$ & $299(3.0)$ & $2(0.2)$ & $316(2.6)$ & $<0.0001$ \\
\hline Urgent & $2(0.2)$ & $34(0.3)$ & 0 & $36(0.3)$ & $<0.0001$ \\
\hline Elective & $13(1.2)$ & $265(2.6)$ & $2(0.2)$ & $280(2.3)$ & $<0.0001$ \\
\hline Medical therapy & $128(11.5)$ & $2391(23.7)$ & $869(72.0)$ & $3388(27.3)$ & $<0.0001$ \\
\hline
\end{tabular}

Table 3. In-Hospital Outcomes

\begin{tabular}{|c|c|c|c|c|c|}
\hline Variable & $\begin{array}{l}\text { Young Patients } \\
\quad(n=1109)\end{array}$ & $\begin{array}{l}\text { Middle-Aged to Old } \\
\text { Patients }(n=10,093)\end{array}$ & $\begin{array}{l}\text { Elderly Patients } \\
\quad(n=1207)\end{array}$ & $\begin{array}{c}\text { Total } \\
(\mathrm{n}=12,409)\end{array}$ & $P$ Value \\
\hline Heart failure, $\mathrm{n}(\%)$ & $79(7.1)$ & $1567(15.5)$ & $330(27.4)$ & $1976(15.9)$ & $<0.0001$ \\
\hline $\begin{array}{l}\text { Ventricular fibrillation/ } \\
\text { sustained ventricular tachycardia, n (\%) }\end{array}$ & $79(7.1)$ & $932(9.2)$ & $87(7.2)$ & $1098(8.9)$ & 0.007 \\
\hline Acute renal failure, $\mathrm{n}(\%)$ & $22(2.0)$ & $690(6.8)$ & $193(16.0)$ & $905(7.3)$ & $<0.0001$ \\
\hline Stroke, $\mathrm{n}(\%)$ & $7(0.6)$ & $176(1.7)$ & $29(2.4)$ & $212(1.7)$ & 0.004 \\
\hline Ischaemic & $4(0.3)$ & $147(1.4)$ & $23(1.9)$ & $174(1.4)$ & 0.004 \\
\hline Haemorrhagic & $3(0.3)$ & $27(0.3)$ & $5(0.4)$ & $35(0.3)$ & 0.66 \\
\hline Left ventricular ejection fraction $<50 \%, \mathrm{n}(\%)$ & $587(52.9)$ & $5877(58.2)$ & $613(50.8)$ & $7077(57.0)$ & 0.0001 \\
\hline In-hospital mortality, n (\%) & $30(2.7)$ & $1131(11.2)$ & $465(38.5)$ & $1626(13.1)$ & $<0.0001$ \\
\hline
\end{tabular}


an independent protective factor amongst all 3 age groups (HR $0.47,95 \%$ CI $0.34-0.65$; HR $0.48,95 \%$ CI $0.38-0.61$; HR $0.04,95 \%$ CI $0.007-0.25$; respectively).

Figure 1 shows the long-term mortality outcomes between the 3 age groups with elderly patients having significantly higher 30-day, 1-year and 2-year mortality compared to MAO and young patients. The survival curve of patients with STEMI compared amongst the 3 age groups is shown in Figure 2. The significant univariate and multivariate predictors of 1-year mortality of the total cohort and each age group is described in Supplementary Tables 1 to 4.

Table 4. Independent Predictors and Protective Factors of 1-Year Mortality

\begin{tabular}{|c|c|c|}
\hline Independent Predictor & $\begin{array}{c}\text { Hazard } \\
\text { Ratio }\end{array}$ & $\begin{array}{l}\text { 95\% Confidence } \\
\text { Interval }\end{array}$ \\
\hline \multicolumn{3}{|l|}{ Young patients $(\mathrm{n}=1109)$} \\
\hline Creatinine $($ per $\mu \mathrm{mol} / \mathrm{L})$ & 1.01 & $1.00-1.02$ \\
\hline \multicolumn{3}{|l|}{ Middle-aged to old patients $(n=10,093)$} \\
\hline Age (per year) & 1.049 & $1.038-1.060$ \\
\hline Creatinine (per $\mu \mathrm{mol} / \mathrm{L})$ & 1.0006 & $1.0001-1.0010$ \\
\hline Malay ethnicity & 1.26 & $1.02-1.55$ \\
\hline Hypertension & 1.34 & $1.08-1.67$ \\
\hline Diabetes mellitus & 1.46 & $1.21-1.76$ \\
\hline Killip class III heart failure & 1.75 & $1.34-2.29$ \\
\hline Killip class IV heart failure & 1.52 & $1.04-2.23$ \\
\hline \multicolumn{3}{|l|}{ Elderly patients $(\mathrm{n}=1207)$} \\
\hline Previous AMI & 1.98 & $1.45-2.72$ \\
\hline Killip Class II heart failure & 1.44 & $1.03-2.02$ \\
\hline Creatinine (per $\mu \mathrm{mol} / \mathrm{L})$ & 1.0017 & $1.0007-1.0028$ \\
\hline Independent Protective Factor & $\begin{array}{c}\text { Hazard } \\
\text { Ratio }\end{array}$ & $\begin{array}{l}\text { 95\% Confidence } \\
\text { Interval }\end{array}$ \\
\hline \multicolumn{3}{|l|}{ Young patients $(\mathrm{n}=1109)$} \\
\hline Prescribed statin on discharge & 0.04 & $0.007-0.25$ \\
\hline \multicolumn{3}{|l|}{ Middle-aged to old patients $(n=10,093)$} \\
\hline Haemoglobin (per g/dL) & 0.89 & $0.86-0.93$ \\
\hline Treatment: PCI only & 0.45 & $0.36-0.55$ \\
\hline Treatment: CABG only & 0.36 & $0.18-0.74$ \\
\hline Treatment: mixed revascularisation* & 0.27 & $0.15-0.48$ \\
\hline Prescribed aspirin on discharge & 0.65 & $0.52-0.83$ \\
\hline Prescribed beta-blocker on discharge & 0.71 & $0.58-0.88$ \\
\hline Prescribed ACE inhibitor on discharge & 0.72 & $0.60-0.87$ \\
\hline Prescribed statin on discharge & 0.48 & $0.38-0.61$ \\
\hline \multicolumn{3}{|l|}{ Elderly patients $(\mathrm{n}=1207)$} \\
\hline Treatment: PCI only & 0.44 & $0.30-0.64$ \\
\hline Prescribed aspirin on discharge & 0.68 & $0.50-0.92$ \\
\hline Prescribed statin on discharge & 0.47 & $0.34-0.65$ \\
\hline
\end{tabular}

ACE: Angiotensin converting enzyme; CABG: Coronary artery bypass graft; PCI: Percutaneous coronary intervention

*Refers to either PCI, CABG or thrombolysis.

\section{Discussion}

In this study, we sought to investigate and understand the differences in presentation, clinical characteristics, treatment received and outcomes in the different age groups of patients. The findings showed significant differences in the various groups and shed important light on the variability in the extremes of age in this cohort.

The distribution of risk factors varies significantly amongst the 3 groups. The young had a significantly lower prevalence of cardiovascular risk factors as compared to older patientswith the exception of smoking, hyperlipidaemia and higher BMI-which is consistent with studies in Japan. ${ }^{18}$ Smoking and hyperlipidaemia are known risk factors for coronary atherosclerosis in the young. ${ }^{23}$ These risk factors are modifiable and represent an opportunity for public health interventions to prevent cardiovascular disease in the young.

In our study, there was a lower rate of PCI amongst the elderly as compared to MAO and young patients $(26.0 \%$ vs $72.4 \%$ vs $85.5 \%$, respectively; $P<0.0001)$. This lower rate of revascularisation in the elderly is well described in both Western and Asian populations. ${ }^{24-26}$ Other studies

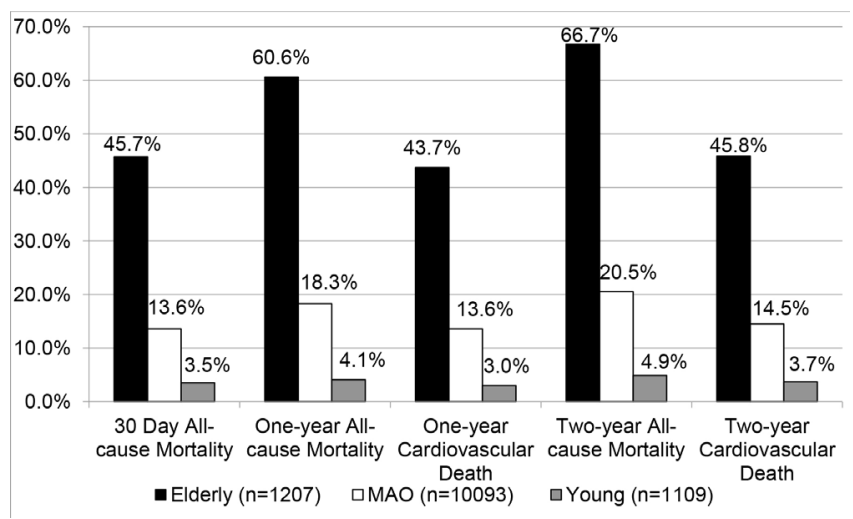

Fig. 1. Graph showing mortality outcomes by age group.

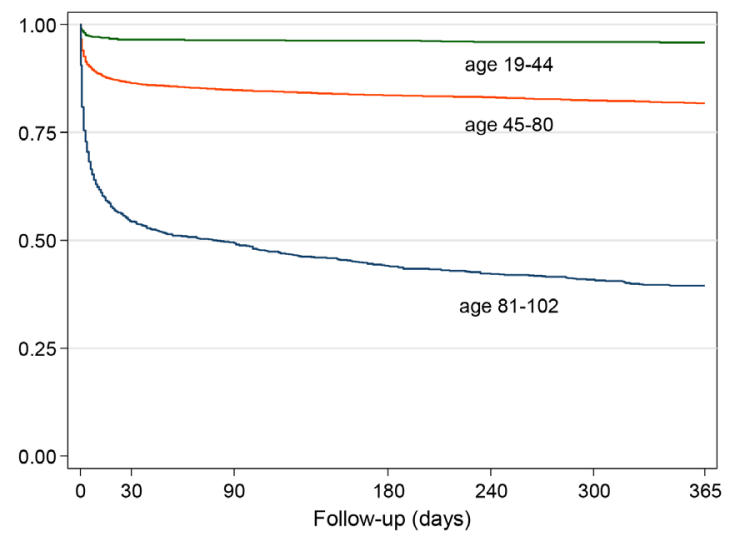

Fig. 2. Graph showing survival curves by age groups. 
suggested reasons for this trend such as the elderly having delayed diagnosis due to atypical symptoms and abnormal resting electrocardiograms or comorbidities that are contraindications to reperfusion. ${ }^{27,28}$ Current guidelines recommend coronary revascularisation as standard of care for STEMI in elderly patients. ${ }^{10,12}$ Revascularisation in the elderly has mortality benefit and improves quality of life. The Alberta Provincial Project for Outcomes Assessment in Coronary Heart Disease study demonstrated that elderly patients undergoing revascularisation had greater absolute risk reductions in mortality at 4 years, ${ }^{29}$ as well as improved quality of life at 1 and 3 years, when compared to younger patients. ${ }^{30}$ Supporting this, PCI was an independent negative predictor of 1-year mortality in the elderly (HR $0.44,95 \%$ CI $0.30-0.64$ ) in our study. There is room to study the reasons why the rates of guideline-recommended revascularisation are lower in the elderly.

In this study, the rate of PCI per STEMI in the elderly is similar to that of other countries. PCI per STEMI ranged from $19.7 \%$ (in 2007) to $31.2 \%$ (in 2010) in the Nation-wide Inpatient Sample(NIS) of the United States ${ }^{24}$ compared to an average of $26.0 \%$ in our study (2007-2012). In Singapore, there are additional reasons influencing the decision for revascularisation such as the conservative attitudes of patients towards healthcare. A national survey of senior citizens in Singapore revealed that $10 \%$ of the elderly had financial concerns as a reason for not seeing a doctor when ill and that $44.8 \%$ of elderly were not financially independent when paying for healthcare expenses. ${ }^{31}$ Another local study showed that elderly citizens' top fear about dying was high medical cost (88\%) and being a financial burden to family $(87 \%))^{32}$ These financial concerns could be a barrier to choosing PCI as a treatment strategy for elderly patients in Singapore.

In terms of medical therapy, the elderly also received less guideline-recommended medications on discharge such as aspirin, beta-blockers and angiotensin converting enzyme (ACE) inhibitors as compared to younger patients. These results are consistent with the large multinational Global Registry of Acute Coronary Events. ${ }^{33}$ Postulated reasons for using less antihypertensive agents such as beta-blockers and ACE inhibitors include contraindications such as hypotension and renal impairment. The higher prevalence of acute renal failure $(16.0 \%)$ in the elderly in this study could have hindered the use of ACE inhibitors. Elderly patients had lower mean haemoglobin as compared to MAO and young patients ( 11.8 vs $14.0 \mathrm{vs} 15.3 \mathrm{~g} / \mathrm{dL}$, respectively; $P$ $<0.0001$ ) and the high prevalence of anaemia could have hindered the prescription of aspirin. An American study of 10,018 elderly patients with AMI revealed that one-third of elderly patients did not receive aspirin within the first 2 days of hospitalisation, with those taking aspirin having a $22 \%$ lower 30-day mortality. ${ }^{34}$ In Japan, a study of elderly patients undergoing PCI also revealed that the use of dual antiplatelet therapy and statin therapy was lower in the elderly compared to younger patients. ${ }^{35}$

On multivariate analysis, after adjusting for confounders, age remained a significant predictor of 1-year mortality in the overall cohort. Elderly patients have worse in-hospital outcomes as compared to MAO and young patients with higher rates of in-hospitality mortality (38.5\% vs $11.2 \%$ vs $2.7 \%$, respectively; $P<0.0001)$, renal failure $(16.0 \%$ vs $6.8 \%$ vs $2.0 \%$, respectively; $P<0.0001)$ and stroke $(2.4 \%$ vs $1.7 \%$ vs $0.6 \%$, respectively; $P<0.0004)$. In the NIS, octogenarian patients with STEMI also had higher inhospital mortality, acute renal failure and stroke compared to patients aged $65-79$ years of age. ${ }^{24}$

In the MAO age group, independent predictors of 1-year mortality include classic cardiovascular risk factors such as age, hypertension, diabetes mellitus, renal impairment and Killip III/IV heart failure, as well as previously described protective factors such as treatment with PCI, CABG and guideline-recommended medical therapy. Elderly patients have fewer independent risk factors and protective factors for 1-year mortality. It is possible that the impact of age as a risk factor on 1-year mortality outweighs the other classic cardiovascular risk factors and protective factors. In terms of the protective effect of guideline-recommended medical therapy on 1-year mortality, the elderly benefited similarly from aspirin and statin on discharge compared to MAO patients. Beneficial effects of statin therapy on mortality has been shown in elderly patients with coronary artery disease with greater absolute risk reductions in elderly patients $>80$ years of age. ${ }^{36}$ Further work is needed on the differences in response to antiplatelet and statin therapy in elderly Asians.

Guideline-recommended medical therapy such as beta-blockers and ACE inhibitors were not independent protective factors of 1-year mortality in the elderly. The reduced effect of beta-blockers in advancing age has been previously described, with greater mortality reductions in younger patients compared to older patients. ${ }^{37}$

Within the elderly age group, there were several independent predictors of mortality such as having previous AMI, Killip Class II heart failure and renal impairment. This agrees with a large multicentre study where heart failure and renal impairment were shown to be independent predictors of in-hospital mortality in elderly patients..$^{24}$ In the young, there were few independent predictors of 1-year mortality that reached significance because of the low mortality rate. 


\section{Limitations}

Our study has several limitations. First, the study utilised data from SMIR which is a retrospective, observational registry. However, data collection is state-mandated and audited for clinical accuracy. Second, the SMIR does not systemically collect reasons on why a patient does not undergo revascularisation. This limited the ability of our study to explain why revascularisation rates are so low in the elderly population.

\section{Conclusion}

Elderly patients with STEMI have poorer outcomes than MAO and young patients. This is potentially attributable to a myriad of factors including age, higher burden of comorbidities and a lesser likelihood of receiving revascularisation and guideline-recommended medical therapy. The results of this study reinforce the need for physicians to continue prescribing guidelinerecommended medical therapy to the elderly and to consider revascularisation in suitable patients without excluding the elderly based on advanced age alone. Further studies will need to be conducted to examine the reasons behind the lower rates of revascularisation and medical therapy in the elderly.

\section{Financial Disclosure}

Adj A/Prof Yeo Khung Keong has previously consulted for and received research support from Medtronic and received honorari from Menarini, Astra Zeneca, Amgen, Medtronic, Abbott Vascular, Boston Scientific and St. Jude Medical. A/Prof Marcus Eng Hock Ong has patents titled "Method of predicting acute cardiopulmonary events and survivability of a patient" and "System and method of determining a risk score for triage".

\section{REFERENCES}

1. Lee PY, Alexander KP, Hammill BG, Pasquali SK, Peterson ED. Representation of elderly persons and women in published randomized trials of acute coronary syndromes. JAMA 2001;286:708-13.

2. Dodd KS, Saczynski JS, Zhao Y, Goldberg RJ, Gurwitz JH. Exclusion of older adults and women from recent trials of acute coronary syndromes. J Am Geriatr Soc 2011;59:506-11.

3. D'Agostino RB Sr, Vasan RS, Pencina MJ, Wolf PA, Cobain M, Massaro JM, et al. General cardiovascular risk profile for use in primary care: the Framingham Heart Study. Circulation 2008;117:743-53.

4. Alexander KP, Newby LK, Armstrong PW, Cannon CP, Gibler WB, Rich MW, et al. Acute coronary care in the elderly, part II: ST-segmentelevation myocardial infarction: a scientific statement for healthcare professionals from the American Heart Association Council on Clinical Cardiology: in collaboration with the Society of Geriatric Cardiology. Circulation 2007;115:2570-89.

5. National Registry of Diseases Office, Singapore. Trends in Acute Myocardial Infarction in Singapore 2007-2013. Report No. 3. Available at: https://www.nrdo.gov.sg/publications/ami. Accessed on 23 January 2016.
6. Ting P, Chua TS, Wong A, Sim LL, Tan VW, Koh TH. Trends in mortality from acute myocardial infarction in the coronary care unit. Ann Acad Med Singapore 2007;36:974-9.

7. Gharacholou SM, Lopes RD, Alexander KP, Mehta RH, Stebbins AL, Pieper KS, et al. Age and outcomes in ST-segment elevation myocardial infarction treated with primary percutaneous coronary intervention: findings from the APEX-AMI trial. Arch Intern Med 2011;171:559-67.

8. Batchelor WB, Anstrom KJ, Muhlbaier LH, Grosswald R, Weintraub WS, O'Neill WW, et al. Contemporary outcome trends in the elderly undergoing percutaneous coronary interventions: results in 7,472 octogenarians. National Cardiovascular Network Collaboration. J Am Coll Cardiol 2000 Sep;36:723-30.

9. Sandhu K, Nadar SK. Percutaneous coronary intervention in the elderly. Int J Cardiol 2015;199:342-55.

10. O'Gara PT, Kushner FG, Ascheim DD, Casey DE Jr, Chung MK, de Lemos JA, et al. 2013 ACCF/AHA guideline for the management of ST-elevation myocardial infarction: executive summary: a report of the American College of Cardiology Foundation/American HeartAssociation Task Force on Practice Guidelines. J Am Coll Cardiol 2013;61:485-510.

11. Lim HS, Andrianopoulos N, Sugumar H, Stub D, Brennan AL, Lim CC, et al. Long-term survival of elderly patients undergoing percutaneous coronary intervention for myocardial infarction complicated by cardiogenic shock. Int J Cardiol 2015;195:259-64.

12. Ibanez B, James S, Agewall S, Antunes MJ, Bucciarelli-Ducci C, Bueno $\mathrm{H}$, et al. 2017 ESC Guidelines for the management of acute myocardial infarction in patients presenting with ST-segment elevation: the task force for the management of acute myocardial infarction in patients presenting with ST-segment elevation of the European Society of Cardiology (ESC). Eur Heart J 2018;39:119-77.

13. Kireyev D, Tan HC, Poh KK. Management of acute ST-elevation myocardial infarction: reperfusion options. Ann Acad Med Singapore 2010;39:927-7.

14. Chua SK, Hung HF, Shyu KG, Cheng JJ, Chiu CZ, Chang CM, et al. Acute ST-elevation myocardial infarction in young patients: 15 years of experience in a single center. Clin Cardiol 2010;33:140-8.

15. Zimmerman FH, Cameron A, Fisher LD, Ng G. Myocardial infarction in young adults: angiographic characterization, risk factors and prognosis (Coronary Artery Surgery Study Registry). J Am Coll Cardiol 1995;26:654-61.

16. Waziri H, Jorgensen E, Kelbaek H, Stagmo M, Pedersen F, Lagerqvist B, et al. Short and long-term survival after primary percutaneous coronary intervention in young patients with ST-elevation myocardial infarction. Int J Cardiol 2016;203:697-701.

17. Konishi H, Miyauchi K, Kasai T, Tsuboi S, Ogita M, Naito R, et al. Long-term prognosis and clinical characteristics of young adults $(\leq 40$ years old) who underwent percutaneous coronary intervention. J Cardiol 2014;64:171-4.

18. Shiraishi J, Kohno Y, Yamaguchi S, Arihara M, Hadase M, Hyogo M, et al. Acute myocardial infarction in young Japanese adults. Circ J 2005; 9:1454-8.

19. Zheng H, Pek PP, Ho AF, Wah W, Foo LL, Li JQ, et al. Ethnic differences and trends in ST-segment elevation myocardial infarction incidence and mortality in a multi-ethnic population. Ann Acad Med Singapore 2019;48:75-85.

20. Xie CB, Chan MY, Teo SG, Low AF, Tan HC, Lee CH. Acute myocardial infarction in young Asian women: a comparative study on Chinese, Malay and Indian ethnic groups. Singapore Med J 2011;52:835-9.

21. National Registry of Diseases Office, Singapore. Acute Myocardial Infarction(AMI): The Singapore Myocardial Infarction Registry (SMIR) Collects Information on Acute MyocardiaI Infarction, More Commonly Known As a Heart Attack. Available at: https://www.nrdo.gov.sg/ publications/ami. Accessed on 23 January 2016. 
22. Centers for Disease Control and Prevention. National Center for Health Statistics. International Classification of Diseases,Ninth Revision, Clinical Modification (ICD-9-CM). 2011

23. McGill HC Jr, McMahan CA, Malcom GT, Oalmann MC, Strong JP. Effects of serum lipoproteins and smoking on atherosclerosis in young men and women. The PDAY Research Group. Pathobiological determinants of atherosclerosis in youth. Arterioscler Thromb Vasc Biol 1997; 17:95-106.

24. Khera S, Kolte D, Palaniswamy C, Mujib M, Aronow WS, Singh T, et al. ST-elevation myocardial infarction in the elderly - temporal trends in incidence, utilization of percutaneous coronary intervention and outcomes in the United States. Int J Cardiol 2013;168:3683-90.

25. Zuhdi ASM, Ahmad WAW, Zaki RA, Mariapun J, Ali RM, Sari NM, et al. Acute coronary syndrome in the elderly: the Malaysian National Cardiovascular Disease Database-Acute Coronary Syndrome registry. Singapore Med J 2016;57:191-7.

26. Alexander KP, Newby LK, Bhapkar MV, White HD, Hochman JS, Pfisterer $\mathrm{ME}$, et al. International variation in invasive care of the elderly with acute coronary syndromes. Eur Heart J 2006;27:1558-64.

27. Woon VC, Lim KH. Acute myocardial infarction in the elderly - the differences compared with the young. Singapore Med J 2003;44:414-8.

28. Wood FO, Leonowicz NA, Vanhecke TE, Dixon SR, Grines CL. Mortality in patients with ST-segment elevation myocardial infarction who do not undergo reperfusion. Am J Cardiol 2012;110:509-14.

29. Graham MM, Ghali WA, Faris PD, Galbraith PD, Norris CM, Knudtson ML. Survival after coronary revascularization in the elderly. Circulation 2002;105:2378-84.

30. Graham MM, Norris CM, Galbraith PD, Knudtson ML, Ghali WA. Quality of life after coronary revascularization in the elderly. Eur Heart J 2006;27:1690-8.
31. Ministry of Social and Family Development, Singapore. National Survey of Senior Citizens 2011. Available at: https://www.msf.gov. sg/publications/Pages/National-Survey-of-Senior-Citizens-2011.aspx. Accessed on 1 August 2016.

32. Blackbox Research. Lien Foundation Survey on Death Attitudes. Available at: http://lienfoundation.org/sites/default/files/Lien $\% 20 \% 20$ Foundation\%20Doctors\%20and\%20Nurses\%20Report 18\%20June 14 for\%20uploading\%20on\%20website_0.pdf.Accessed on 1 August 2016.

33. Nguyen HL, Goldberg RJ, Gore JM, Fox KA, Eagle KA, Gurfinkel $\mathrm{EP}$, et al. Age and sex differences, and changing trends, in the use of evidence-based therapies in acute coronary syndromes: perspectives from a multinational registry. Coron Artery Dis 2010 Sep;21:336-44.

34. Krumholz HM, Radford MJ, Ellerbeck EF, Hennen J, Meehan TP, Petrillo $\mathrm{M}$, et al. Aspirin in the treatment of acute myocardial infarction in elderly Medicare beneficiaries. Patterns of use and outcomes. Circulation 1995;92:2841-7.

35. Kaneko H, Yajima J, Oikawa Y, Tanaka S, Fukamachi D, Suzuki S, et al. Impact of aging on the clinical outcomes of Japanese patients with coronary artery disease after percutaneous coronary intervention. Heart and Vessels 2014;29:156-64.

36. Allen Maycock CA, Muhlestein JB, Horne BD, Carlquist JF, Bair TL, Pearson RR, et al. Statin therapy is associated with reduced mortality across all age groups of individuals with significant coronary disease, including very elderly patients. J Am Coll Cardiol 2002;40:1777-85.

37. Soumerai SB, McLaughlin TJ, Spiegelman D, Hertzmark E, Thibault G, Goldman L. Adverse outcomes of underuse of beta-blockers in elderly survivors of acute myocardial infarction. JAMA 1997;277:115-21.

Supplementary Table 1. Significant Univariate and Multivariate Predictors of 1-Year Mortality in Overall Cohort

\begin{tabular}{|c|c|c|c|c|c|c|}
\hline \multirow[t]{2}{*}{ Patients $(n=12,409)$} & \multicolumn{2}{|c|}{$\begin{array}{c}\text { Unadjusted Hazard Ratio, 95\% } \\
\text { Confidence Interval }\end{array}$} & \multicolumn{2}{|c|}{$\begin{array}{l}\text { Adjusted Hazard Ratio Model } \\
\text { Without Discharge Medication }\end{array}$} & \multicolumn{2}{|c|}{$\begin{array}{l}\text { Adjusted Hazard Ratio Model } \\
\text { With Discharge Medication }\end{array}$} \\
\hline & Hazard Ratio & $\begin{array}{l}\text { 95\% Confidence } \\
\text { Interval }\end{array}$ & Hazard Ratio & $\begin{array}{l}\text { 95\% Confidence } \\
\text { Interval }\end{array}$ & Hazard Ratio & $\begin{array}{l}\text { 95\% Confidence } \\
\text { Interval }\end{array}$ \\
\hline Male gender & 0.37 & $0.34-0.40$ & 0.89 & $0.80-0.99$ & 0.83 & $0.69-1.00$ \\
\hline \multicolumn{7}{|l|}{ Age, years } \\
\hline $18-44$ & \multicolumn{2}{|c|}{ Reference } & \multicolumn{2}{|c|}{ Reference } & \multicolumn{2}{|c|}{ Reference } \\
\hline $45-80$ & 4.73 & $3.53-6.34$ & 2.74 & $1.97-3.81$ & 3.30 & $1.81-6.03$ \\
\hline $81-102$ & 20.5 & $15.2-27.6$ & 5.22 & $3.71-7.36$ & 6.99 & $3.74-13.06$ \\
\hline \multicolumn{7}{|l|}{ Ethnicity } \\
\hline Chinese & \multicolumn{2}{|c|}{ Reference } & \multicolumn{2}{|c|}{ Reference } & \multicolumn{2}{|c|}{ Reference } \\
\hline Malay & 0.94 & $0.85-1.03$ & 1.05 & $0.94-1.17$ & 1.20 & $1.00-1.44$ \\
\hline Indian & 0.63 & $0.56-0.72$ & 0.89 & $0.77-1.02$ & 0.95 & $0.75-1.20$ \\
\hline Others & 0.69 & $0.48-0.98$ & 1.03 & $0.70-1.51$ & 0.79 & $0.38-1.68$ \\
\hline \multicolumn{7}{|l|}{ Risk factors } \\
\hline Hypertension & 1.70 & $1.57-1.85$ & 1.09 & $0.99-1.21$ & 1.24 & $1.03-1.49$ \\
\hline Diabetes mellitus & 1.69 & $1.57-1.82$ & 1.20 & $1.10-1.32$ & 1.43 & $1.22-1.67$ \\
\hline Hyperlipidaemia & 1.07 & $0.99-1.15$ & NA & NA & NA & NA \\
\hline Previous AMI & 1.72 & $1.55-1.91$ & 1.29 & $1.14-1.46$ & 1.34 & $1.08-1.65$ \\
\hline Previous CABG & 1.85 & $1.47-2.34$ & 1.12 & $0.87-1.44$ & 1.07 & $0.69-1.64$ \\
\hline Previous PCI & 0.83 & $0.71-0.98$ & 0.89 & $0.74-1.08$ & 1.17 & $0.88-1.56$ \\
\hline Ever smoker & 0.52 & $0.48-0.57$ & 0.98 & $0.89-1.09$ & 1.10 & $0.93-1.31$ \\
\hline
\end{tabular}

ACE: Angiotensin converting enzyme; AMI: Acute myocardial infarction; CABG: Coronary artery bypass graft; NA: Not applicable; PCI: Percutaneous coronary intervention 
Supplementary Table 1. Significant Univariate and Multivariate Predictors of 1-Year Mortality in Overall Cohort (Cont'd)

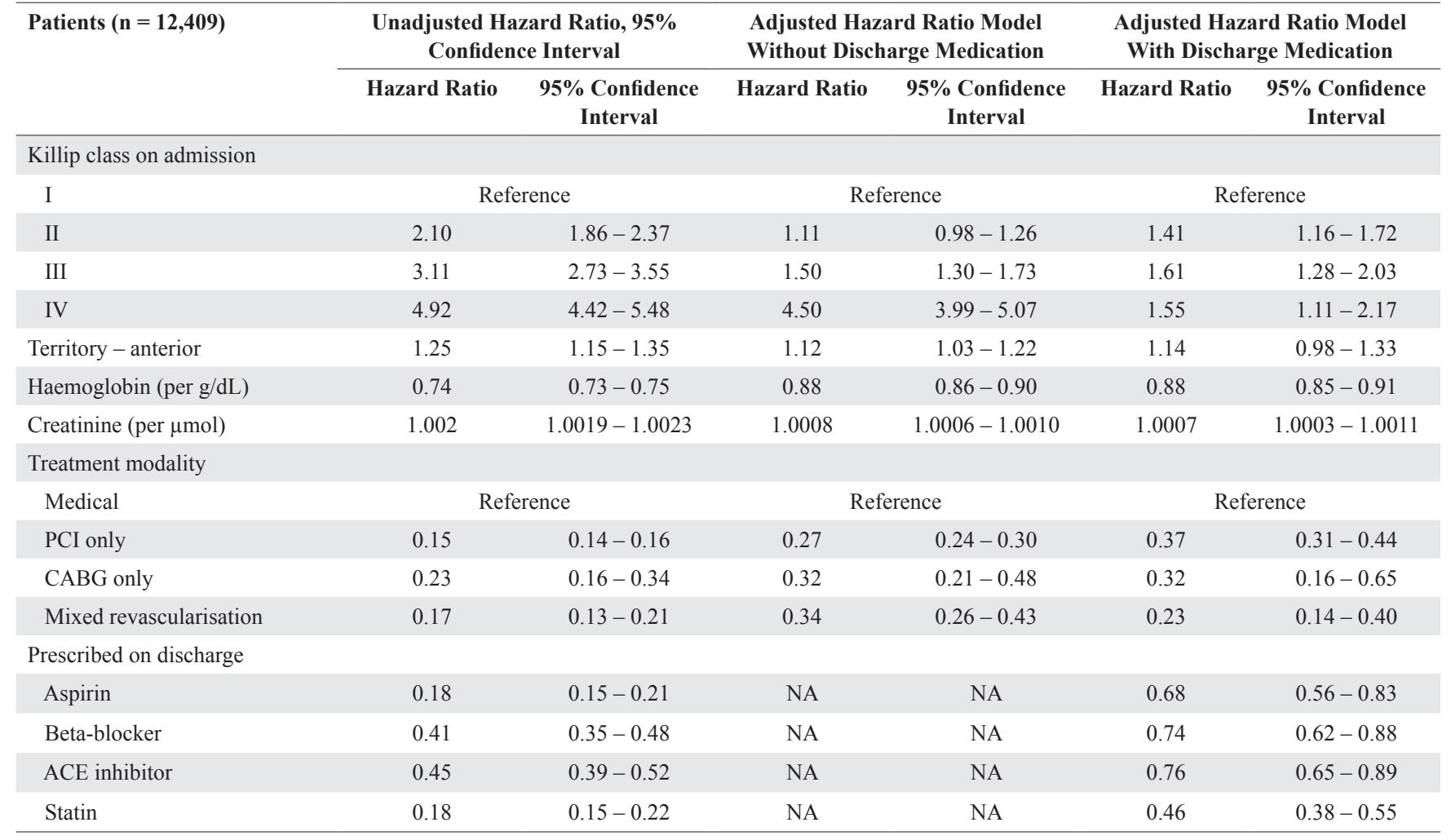

ACE: Angiotensin converting enzyme; AMI: Acute myocardial infarction; CABG: Coronary artery bypass graft; NA: Not applicable; PCI: Percutaneous coronary intervention

Supplementary Table 2. Significant Univariate and Multivariate Predictors of 1-Year Mortality in Young Patients

\begin{tabular}{|c|c|c|c|c|c|c|}
\hline \multirow[t]{2}{*}{ Patients $(n=1109)$} & \multicolumn{2}{|c|}{$\begin{array}{c}\text { Unadjusted Hazard Ratio, 95\% } \\
\text { Confidence Interval }\end{array}$} & \multicolumn{2}{|c|}{$\begin{array}{l}\text { Adjusted Hazard Ratio Model } \\
\text { Without Discharge Medication }\end{array}$} & \multicolumn{2}{|c|}{$\begin{array}{l}\text { Adjusted Hazard Ratio Model } \\
\text { With Discharge Medication }\end{array}$} \\
\hline & Hazard Ratio & $\begin{array}{l}\text { 95\% Confidence } \\
\text { Interval }\end{array}$ & Hazard Ratio & $\begin{array}{l}\text { 95\% Confidence } \\
\text { Interval }\end{array}$ & Hazard Ratio & $\begin{array}{l}\text { 95\% Confidence } \\
\text { Interval }\end{array}$ \\
\hline Male gender & 0.28 & $0.14-0.58$ & 0.72 & $0.26-1.99$ & 1.62 & $0.13-19.8$ \\
\hline Age, years & 1.04 & $0.96-1.13$ & NA & NA & NA & NA \\
\hline \multicolumn{7}{|l|}{ Ethnicity } \\
\hline Chinese & \multicolumn{2}{|c|}{ Reference } & \multicolumn{2}{|c|}{ Reference } & \multicolumn{2}{|c|}{ Reference } \\
\hline Malay & 1.89 & $0.97-3.69$ & 1.50 & $0.64-3.51$ & 2.14 & $0.32-14.2$ \\
\hline Indian & 0.87 & $0.38-1.98$ & 1.10 & $0.43-2.79$ & 2.75 & $0.49-15.5$ \\
\hline Others & 3.88 & $1.15-13.1$ & 4.85 & $1.31-17.9$ & 12.2 & $0.94-157.4$ \\
\hline \multicolumn{7}{|l|}{ Risk factors } \\
\hline Hypertension & 1.23 & $0.68-2.21$ & NA & NA & NA & NA \\
\hline Hyperlipidaemia & 1.03 & $0.55-1.93$ & NA & NA & NA & NA \\
\hline Previous AMI & 1.18 & $0.37-3.79$ & NA & NA & NA & NA \\
\hline Previous CABG & 42.23 & $5.73-311.2$ & NA & NA & NA & NA \\
\hline Previous PCI & NA & NA & NA & NA & NA & NA \\
\hline Ever smoker & 0.34 & $0.18-0.65$ & 0.42 & $0.20-0.88$ & 0.32 & $0.08-1.29$ \\
\hline
\end{tabular}

ACE: Angiotensin converting enzyme; AMI: Acute myocardial infarction; CABG: Coronary artery bypass graft; NA: Not applicable; PCI: Percutaneous coronary intervention 
Supplementary Table 2. Significant Univariate and Multivariate Predictors of 1-Year Mortality in Young Patients (Cont'd)

\begin{tabular}{|c|c|c|c|c|c|c|}
\hline \multirow[t]{2}{*}{ Patients $(n=1109)$} & \multicolumn{2}{|c|}{$\begin{array}{c}\text { Unadjusted Hazard Ratio, 95\% } \\
\text { Confidence Interval }\end{array}$} & \multicolumn{2}{|c|}{$\begin{array}{l}\text { Adjusted Hazard Ratio Model } \\
\text { Without Discharge Medication }\end{array}$} & \multicolumn{2}{|c|}{$\begin{array}{c}\text { Adjusted Hazard Ratio Model } \\
\text { With Discharge Medication }\end{array}$} \\
\hline & Hazard Ratio & $\begin{array}{l}\text { 95\% Confidence } \\
\text { Interval }\end{array}$ & Hazard Ratio & $\begin{array}{l}\text { 95\% Confidence } \\
\text { Interval }\end{array}$ & Hazard Ratio & $\begin{array}{l}\text { 95\% Confidence } \\
\text { Interval }\end{array}$ \\
\hline \multicolumn{7}{|l|}{ Killip class on admission } \\
\hline I & \multicolumn{2}{|c|}{ Reference } & \multicolumn{2}{|c|}{ Reference } & \multicolumn{2}{|c|}{ Reference } \\
\hline II & 2.09 & $0.50-8.77$ & 1.25 & $0.28-5.57$ & 3.23 & $0.48-21.9$ \\
\hline III & 7.31 & $2.22-24.1$ & 6.54 & $1.80-23.8$ & NA & NA \\
\hline IV & 12.0 & $5.93-24.1$ & 10.6 & $4.64-24.3$ & NA & NA \\
\hline Territory - anterior & 1.96 & $1.06-3.62$ & 1.84 & $0.88-3.85$ & 2.07 & $0.50-8.65$ \\
\hline Haemoglobin (per g/dL) & 0.73 & $0.65-0.82$ & 0.90 & $0.76-1.08$ & 0.86 & $0.58-1.27$ \\
\hline Creatinine (per $\mu \mathrm{mol}$ ) & 1.0024 & $0.0015-1.0034$ & 1.0051 & $1.0020-1.0082$ & 1.01 & $1.00-1.02$ \\
\hline \multicolumn{7}{|l|}{ Treatment modality } \\
\hline PCI only & 0.21 & $0.11-0.38$ & 0.59 & $0.26-1.36$ & 1.65 & $0.25-10.7$ \\
\hline CABG only & 0.64 & $0.09-4.84$ & 0.43 & $0.04-4.28$ & NA & NA \\
\hline Mixed (including thrombolysis) & 0.14 & $0.02-1.04$ & 0.46 & $0.05-3.90$ & NA & NA \\
\hline \multicolumn{7}{|l|}{ Prescribed on discharge } \\
\hline Aspirin & 0.25 & $0.05-1.13$ & NA & NA & NA & NA \\
\hline Beta-blocker & 0.19 & $0.06-0.65$ & NA & NA & 0.53 & $0.11-2.66$ \\
\hline ACE inhibitor & 0.29 & $0.09-0.96$ & NA & NA & 0.32 & $0.08-1.23$ \\
\hline Statin & 0.08 & $0.02-0.30$ & NA & NA & 0.04 & $0.007-0.25$ \\
\hline
\end{tabular}

ACE: Angiotensin converting enzyme; AMI: Acute myocardial infarction; CABG: Coronary artery bypass graft; NA: Not applicable; PCI: Percutaneous coronary intervention

Supplementary Table 3. Significant Univariate and Multivariate Predictors of 1-Year Mortality in Middle-Aged to Old Patients

\begin{tabular}{|c|c|c|c|c|c|c|}
\hline \multirow[t]{2}{*}{ Patients $(n=10,093)$} & \multicolumn{2}{|c|}{$\begin{array}{c}\text { Unadjusted Hazard Ratio, 95\% } \\
\text { Confidence Interval }\end{array}$} & \multicolumn{2}{|c|}{$\begin{array}{l}\text { Adjusted Hazard Ratio Model } \\
\text { Without Discharge Medication }\end{array}$} & \multicolumn{2}{|c|}{$\begin{array}{l}\text { Adjusted Hazard Ratio Model } \\
\text { With Discharge Medication }\end{array}$} \\
\hline & Hazard Ratio & $\begin{array}{l}\text { 95\% Confidence } \\
\text { Interval }\end{array}$ & Hazard Ratio & $\begin{array}{l}\text { 95\% Confidence } \\
\text { Interval }\end{array}$ & Hazard Ratio & $\begin{array}{l}\text { 95\% Confidence } \\
\text { Interval }\end{array}$ \\
\hline Male gender & 0.44 & $0.40-0.48$ & 0.97 & $0.85-1.11$ & 0.86 & $0.69-1.07$ \\
\hline Age, years & 1.073 & $1.068-1.078$ & 1.046 & $1.039-1.052$ & 1.049 & $1.038-1.060$ \\
\hline \multicolumn{7}{|l|}{ Ethnicity } \\
\hline Chinese & \multicolumn{2}{|c|}{ Reference } & \multicolumn{2}{|c|}{ Reference } & \multicolumn{2}{|c|}{ Reference } \\
\hline Malay & 1.12 & $1.00-1.25$ & 1.08 & $0.96-1.22$ & 1.26 & $1.02-1.55$ \\
\hline Indian & 0.76 & $0.65-0.88$ & 1.01 & $0.86-1.20$ & 1.08 & $0.82-1.41$ \\
\hline Others & 0.69 & $0.44-1.07$ & 1.12 & $0.69-1.81$ & 0.98 & $0.44-2.21$ \\
\hline \multicolumn{7}{|l|}{ Risk factors } \\
\hline Hypertension & 1.61 & $1.46-1.77$ & 1.04 & $0.93-1.18$ & 1.34 & $1.08-1.67$ \\
\hline Diabetes mellitus & 1.78 & $1.62-1.95$ & 1.22 & $1.09-1.36$ & 1.46 & $1.21-1.76$ \\
\hline Hyperlipidaemia & 1.07 & $0.98-1.17$ & NA & NA & NA & NA \\
\hline Previous AMI & 1.61 & $1.42-1.83$ & 1.13 & $0.99-1.30$ & 1.18 & $0.93-1.50$ \\
\hline Previous CABG & 1.89 & $1.45-2.47$ & 1.24 & $0.93-1.65$ & 1.17 & $0.72-1.92$ \\
\hline Previous PCI & 0.90 & $0.75-1.08$ & - & & - & \\
\hline Ever smoker & 0.62 & $0.56-0.68$ & 1.02 & $0.91-1.15$ & 1.21 & $0.98-1.48$ \\
\hline
\end{tabular}

ACE: Angiotensin converting enzyme; AMI: Acute myocardial infarction; CABG: Coronary artery bypass graft; NA: Not applicable; PCI: Percutaneous coronary intervention 
Supplementary Table 3. Significant Univariate and Multivariate Predictors of 1-Year Mortality in Middle-Aged to Old Patients (Cont'd)

\begin{tabular}{|c|c|c|c|c|c|c|}
\hline \multirow[t]{2}{*}{ Patients $(n=1109)$} & \multicolumn{2}{|c|}{$\begin{array}{c}\text { Unadjusted Hazard Ratio, 95\% } \\
\text { Confidence Interval }\end{array}$} & \multicolumn{2}{|c|}{$\begin{array}{l}\text { Adjusted Hazard Ratio Model } \\
\text { Without Discharge Medication }\end{array}$} & \multicolumn{2}{|c|}{$\begin{array}{l}\text { Adjusted Hazard Ratio Model } \\
\text { With Discharge Medication }\end{array}$} \\
\hline & Hazard Ratio & $\begin{array}{l}\text { 95\% Confidence } \\
\text { Interval }\end{array}$ & Hazard Ratio & $\begin{array}{l}\text { 95\% Confidence } \\
\text { Interval }\end{array}$ & Hazard Ratio & $\begin{array}{l}\text { 95\% Confidence } \\
\text { Interval }\end{array}$ \\
\hline \multicolumn{7}{|l|}{ Killip class on admission } \\
\hline I & \multicolumn{2}{|c|}{ Reference } & \multicolumn{2}{|c|}{ Reference } & \multicolumn{2}{|c|}{ Reference } \\
\hline II & 1.91 & $1.64-2.22$ & 1.00 & $0.85-1.17$ & 1.26 & $0.99-1.60$ \\
\hline III & 3.39 & $2.91-3.95$ & 1.58 & $1.34-1.87$ & 1.75 & $1.34-2.29$ \\
\hline IV & 5.60 & $4.95-6.32$ & 5.21 & $4.55-5.97$ & 1.52 & $1.04-2.23$ \\
\hline Territory - anterior & 1.22 & $1.11-1.33$ & 1.11 & $1.00-1.23$ & 1.18 & $0.99-1.42$ \\
\hline Haemoglobin (per g/dL) & 0.75 & $0.74-0.76$ & 0.90 & $0.88-0.93$ & 0.89 & $0.86-0.93$ \\
\hline Creatinine (per $\mu \mathrm{mol}$ ) & 1.0022 & $1.0020-1.0023$ & 1.0009 & $1.0007-1.0012$ & 1.0006 & $1.0001-1.0010$ \\
\hline \multicolumn{7}{|l|}{ Treatment modality } \\
\hline PCI only & 0.17 & $0.15-0.18$ & 0.28 & $0.25-0.32$ & 0.45 & $0.36-0.55$ \\
\hline CABG only & 0.27 & $0.18-0.40$ & 0.33 & $0.22-0.49$ & 0.36 & $0.18-0.74$ \\
\hline Mixed (including thrombolysis) & 0.17 & $0.13-0.22$ & 0.34 & $0.26-0.45$ & 0.27 & $0.15-0.48$ \\
\hline \multicolumn{7}{|l|}{ Prescribed on discharge } \\
\hline Aspirin & 0.19 & $0.16-0.23$ & NA & NA & 0.65 & $0.52-0.83$ \\
\hline Beta-blocker & 0.49 & $0.40-0.59$ & NA & NA & 0.71 & $0.58-0.88$ \\
\hline ACE inhibitor & 0.49 & $0.42-0.58$ & NA & NA & 0.72 & $0.60-0.87$ \\
\hline Statin & 0.20 & $0.16-0.25$ & NA & NA & 0.48 & $0.38-0.61$ \\
\hline
\end{tabular}

ACE: Angiotensin converting enzyme; AMI: Acute myocardial infarction; CABG: Coronary artery bypass graft; NA: Not applicable; PCI: Percutaneous coronary intervention

Supplementary Table 4. Significant Univariate and Multivariate Predictors of 1-Year Mortality in Elderly Patients

\begin{tabular}{|c|c|c|c|c|c|c|}
\hline \multirow[t]{2}{*}{ Patients $(n=1207)$} & \multicolumn{2}{|c|}{$\begin{array}{c}\text { Unadjusted Hazard Ratio, } 95 \% \\
\text { Confidence Interval }\end{array}$} & \multicolumn{2}{|c|}{$\begin{array}{l}\text { Adjusted Hazard Ratio Model } \\
\text { Without Discharge Medication }\end{array}$} & \multicolumn{2}{|c|}{$\begin{array}{l}\text { Adjusted Hazard Ratio Model } \\
\text { With Discharge Medication }\end{array}$} \\
\hline & Hazard Ratio & $\begin{array}{l}\text { 95\% Confidence } \\
\text { Interval }\end{array}$ & Hazard Ratio & $\begin{array}{l}\text { 95\% Confidence } \\
\text { Interval }\end{array}$ & Hazard Ratio & $\begin{array}{l}\text { 95\% Confidence } \\
\text { Interval }\end{array}$ \\
\hline Male gender & 1.04 & $0.89-1.20$ & NA & NA & NA & NA \\
\hline Age, years & 1.042 & $1.025-1.058$ & 1.033 & $1.015-1.051$ & 1.020 & $0.988-1.053$ \\
\hline \multicolumn{7}{|l|}{ Ethnicity } \\
\hline Chinese & \multicolumn{2}{|c|}{ Reference } & \multicolumn{2}{|c|}{ Reference } & \multicolumn{2}{|c|}{ Reference } \\
\hline Malay & 1.05 & $0.83-1.33$ & NA & NA & NA & NA \\
\hline Indian & 0.95 & $0.71-1.25$ & NA & NA & NA & NA \\
\hline Others & 0.66 & $0.33-1.32$ & NA & NA & NA & NA \\
\hline \multicolumn{7}{|l|}{ Risk factors } \\
\hline Hypertension & 0.96 & $0.82-1.13$ & NA & NA & NA & NA \\
\hline Diabetes mellitus & 1.21 & $1.04-1.41$ & 1.13 & $0.97-1.33$ & 1.13 & $0.85-1.50$ \\
\hline Hyperlipidaemia & 0.90 & $0.78-1.05$ & NA & NA & NA & NA \\
\hline Previous AMI & 1.31 & $1.09-1.57$ & 1.33 & $1.10-1.60$ & 1.98 & $1.45-2.72$ \\
\hline Previous CABG & 0.94 & $0.57-1.54$ & NA & NA & NA & NA \\
\hline Previous PCI & 0.89 & $0.62-1.30$ & NA & NA & NA & NA \\
\hline Ever smoker & 1.05 & $0.88-1.24$ & NA & NA & NA & NA \\
\hline
\end{tabular}

ACE: Angiotensin converting enzyme; AMI: Acute myocardial infarction; CABG: Coronary artery bypass graft; NA: Not applicable; PCI: Percutaneous coronary intervention 
Supplementary Table 4. Significant Univariate and Multivariate Predictors of 1-Year Mortality in Elderly Patients (Cont'd)

\begin{tabular}{|c|c|c|c|c|c|c|}
\hline \multirow[t]{2}{*}{ Patients $(n=1207)$} & \multicolumn{2}{|c|}{$\begin{array}{c}\text { Unadjusted Hazard Ratio, 95\% } \\
\text { Confidence Interval }\end{array}$} & \multicolumn{2}{|c|}{$\begin{array}{l}\text { Adjusted Hazard Ratio Model } \\
\text { Without Discharge Medication }\end{array}$} & \multicolumn{2}{|c|}{$\begin{array}{l}\text { Adjusted Hazard Ratio Model } \\
\text { With Discharge Medication }\end{array}$} \\
\hline & Hazard Ratio & $\begin{array}{l}\text { 95\% Confidence } \\
\text { Interval }\end{array}$ & Hazard Ratio & $\begin{array}{l}\text { 95\% Confidence } \\
\text { Interval }\end{array}$ & Hazard Ratio & $\begin{array}{l}\text { 95\% Confidence } \\
\text { Interval }\end{array}$ \\
\hline \multicolumn{7}{|l|}{ Killip class on admission } \\
\hline I & \multicolumn{2}{|c|}{ Reference } & \multicolumn{2}{|c|}{ Reference } & \multicolumn{2}{|c|}{ Reference } \\
\hline II & 1.23 & $1.01-1.51$ & 1.11 & $0.90-1.35$ & 1.44 & $1.03-2.02$ \\
\hline III & 1.11 & $0.86-1.44$ & 0.99 & $0.76-1.29$ & 0.98 & $0.62-1.53$ \\
\hline IV & 2.21 & $1.72-2.83$ & 2.35 & $1.81-3.05$ & 1.51 & $0.73-3.11$ \\
\hline Territory - anterior & 1.05 & $0.90-1.22$ & NA & NA & NA & NA \\
\hline Haemoglobin (per g/dL) & 0.90 & $0.87-0.93$ & 0.95 & $0.91-0.98$ & 0.97 & $0.90-1.04$ \\
\hline Creatinine (per $\mu \mathrm{mol})$ & 1.0013 & $1.0010-1.0017$ & 1.0008 & $1.0004-1.0012$ & 1.0017 & $1.0007-1.0028$ \\
\hline \multicolumn{7}{|l|}{ Treatment modality } \\
\hline PCI only & 0.39 & $0.31-0.47$ & 0.44 & $0.35-0.54$ & 0.44 & $0.30-0.64$ \\
\hline CABG only & NA & NA & NA & NA & NA & NA \\
\hline Mixed (including thrombolysis) & 0.58 & $0.34-0.98$ & 0.76 & $0.44-1.30$ & 0.21 & $0.03-1.54$ \\
\hline \multicolumn{7}{|l|}{ Prescribed on discharge } \\
\hline Aspirin & 0.41 & $0.31-0.54$ & NA & NA & 0.68 & $0.50-0.92$ \\
\hline Beta-blocker & 0.62 & $0.47-0.82$ & NA & NA & 0.84 & $0.63-1.12$ \\
\hline ACE inhibitor & 0.59 & $0.46-0.78$ & NA & NA & 0.95 & $0.71-1.28$ \\
\hline Statin & 0.34 & $0.25-0.46$ & NA & NA & 0.47 & $0.34-0.65$ \\
\hline
\end{tabular}

ACE: Angiotensin converting enzyme; AMI: Acute myocardial infarction; CABG: Coronary artery bypass graft; NA: Not applicable; PCI: Percutaneous coronary intervention 